\title{
Phenotypic Correlations among Pollen Quality and Morphological Traits of Saintpaulia
}

\author{
Erzsebet BUTA, Maria CANTOR*, Rodica POP, Denisa HORT, Radu E. SESTRAȘ \\ University of Agricultural Sciences and Veterinary Medicine, Faculty of Horticulture, Departmentof Horticulture and Landscaping, 3-5 Mănăstur Str, 400372 Cluj Napoca, \\ Romania;marcantor@yahoo.com ("correspondingauthor)
}

\begin{abstract}
In order to estimate the correlation between pollen viability, germination and the morphological traits, 15 Saintpaulia genotypes were analysed. Pollen viability was obtained by staining with potassium iodide (25\%) and germination was estimated using solid nutrient medium ( $15 \%$ sucrose, $85 \%$ humidity, $22^{\circ} \mathrm{C}$ temperature). Several morphological traits such as number of flowers, diameter of leaves rosette, number of leaves, length and width of leaves and petiole length were evaluated to determine growth indices. The results obtained indicated that 'Hot Pink Bell' genotype achieved the highest number of flowers and the largest diameter of leaves rosette. Genotypes 'Tomahawks' and S. grotei recorded the highest number of leaves. Higher width of leaves values was obtained in 'Aloha Orchid', while genotype 'Park Avenue Blue' was noted for a high length of leaves. Positive correlations were recorded among viability and germination in $S$. jonantha, S. rupicola and S. grotei. Significant positive correlation was registered between pollen viability and the number of flowers, but also between germination and the number of flowers per plant. The results indicated a possible correlation between viability, germination capacity and the morphological traits in most genotypes studied.
\end{abstract}

Keywords: African violet, breeding, germination, number of flowers, morphological traits, viability

\section{Introduction}

The ornamental plant industry follows an upward trend across the globe. The most popular potted plants are Begonia, Ficus, Anthurium, Chrysanthemum, Rosa, Saintpaulia and Spathiphyllum (Ghasemietal., 2012).

Saintpaulia Wendl. are popular ornamental plants all over the world with high economical value in horticulture (Daud and Taha, 2008; Ghasemi et al., 2012; Miranto, 2005). Some species are subject of breeding methods since 100 years ago (Kolehmainen and Korpelainen, 2008). The interest of breeders is to create new cultivars with superior morphological characters; this is the explanation for the existence of more than 2,000 African violet cultivars (Kolehmainen and Mutikainen, 2007).

Fang and Traore (2011) reported that due to various intraspecific hybridizations, spontaneous mutations and selections with ameliorative purposes were obtained for African violets, with an extremely varied palette. This species have a slight tendency to mutations and genetic drift, which creates valuable genetic material resources (Robey, 1988).

African violets (Saintpaulia Wendl.) have a distribution in the Eastern Arc Mountains, in the coastal lowlands in SouthEast Kenya and Eastern Tanzania (Kolehmainen and Korpelainen, 2008; Miranto, 2005). The species in this genus grow and develop in shaded areas with acidic soils, in a climate with high temperatures and humidity (Fang and Traore, 2011).

The African violets have a good capacity of producing ornamental hybrids, but the exogenous factors may sometimes raise incompatibility barriers (Fang and Traore, 2011; Gudadhe and Dhoran, 2012; Harrison et al., 1999).

The purpose of the undertaken research was to select genotypes with characteristics of interest in view of breeding works and to enhance the possibility of enriching the germplasm fund with new genotypes. The study of correlations might contribute to the improvement of the process of choosing the most valuable genitors (Baciu et al., 2010).

The success of breeding depends on various factors, of genetic, climatic and economic order (Kahn et al., 2013). Inducing of artificial variability is based on the knowledge of correlations established between two variables or between different plant characteristics (Barros et al., 2010; Sestraş et al., 2012). In this respect, the current research was initiated to determine the close and direct correlation between genotype, viability and pollen germination and the morphological traits in African violets.

The obtained results allow the selection and recommendation of valuable genotypes in economic terms (Gudadhe and Dhoran, 2012).

\section{Materials and methods}

\section{Plant material and pollen samples}

The biological material was represented by three species and twelve cultivars: 'Red Velvet' (S1), 'Jolly Red' (S2), 'Aloha Orchid' (S3), 'Hot Pink Bell' (S4), 'Park Avenue Blue' (S5), 'Lucky Ladybug' (S6), 'Crimson Ice' (S7), Saintpaulia jonantha 

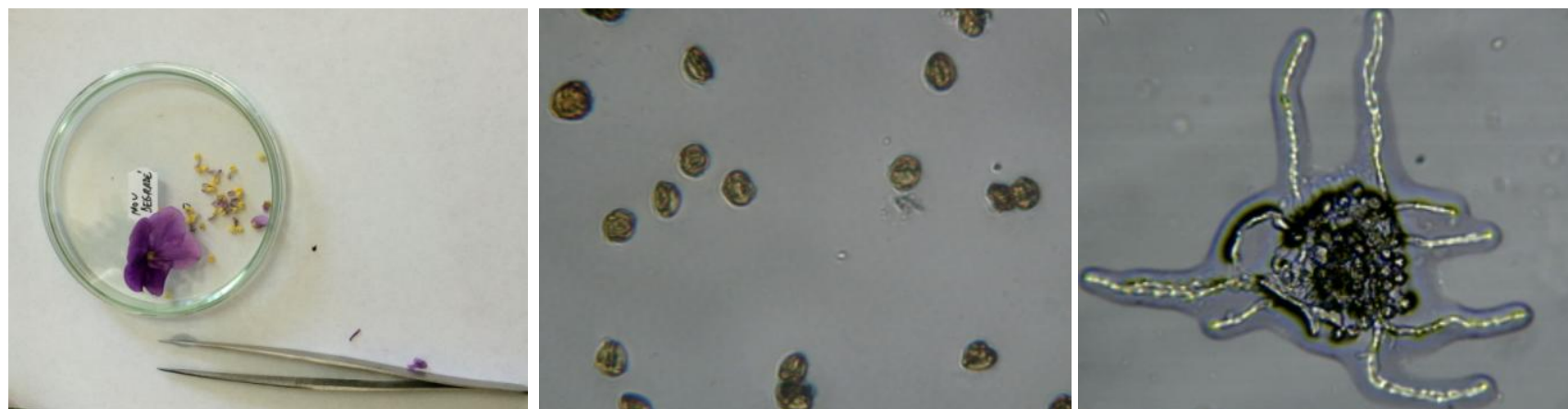

Fig. 1. 'Aloha Orchid's (S3) viability test by staining with potassium iodide (25\%) and pollen grain germination on solid medium (15\% sucrose)

H. Wendl. (S8), 'White Queen' (S9), 'Painted Silk' (S10), 'Pink Pussycat' (S11), 'Buffalo Hunt' (S12), Saintpaulia rupicola B. L. Burtt (S13), 'Tomahawks' (S14), Saintpaulia grotei Engl. (S15). Number of flowers, diameter of leaves rosette, number of leaves, width of leaves, length of leaves and petiole length were measured to calculate several growth indices.

The pollen of 15 Saintpaulia genotypes was collected in October from acclimatized and cultivated plants under the same environmental conditions ( $84 \%$ average air humidity, $23{ }^{\circ} \mathrm{C}$ average temperature) at the didactic greenhouse of the Department of Floriculture within the University of Agricultural Sciences and Veterinary Medicine Cluj-Napoca (UASVM-CN).

\section{Pollen viability test by staining}

In order to determine the viability test, anthers were collected and treated with Carnoy's solution for 2 hours, after which they were washed in $80 \%$ ethanol according to Sestras (2012) and Huang et al. (2004). Ten visual fields were monitored using Aigo Digital Microscope EV5610 (Beijing Aigo Research Institute of Precision Instrument Co., Ltd). Counters were made in five replications for each genotype. The pollen grain that stained brown was considered viable and the transparent one was unviable.

\section{In vitro pollen germination}

To determine germination, pollen grains were sow on solid nutrient medium (15\% sucrose), according to the methodology used by Bodhipadma et al. (2013) and Gudadhe and Dhoran (2012). Counting of pollen grains was made on ten fields in five replications using the same microscope (Fig. 1).

\section{Statisticalanalysis}

Morphological traits of the studied Saintpaulia genotypes were analysed using the ANOVA and means separated with the Duncan's test. The correlations between genotype, pollen viability, germination and different phenotypic traits were performed using Pearson index (Sestrașet al., 2012).

\section{Results and discussions}

\section{Morphological traits}

The variability of morphological traits of the 15 Saintpaulia genotypes is presented in Table 1. According to the obtained results, S4 genotype achieved the highest number of flowers (25.0) and the largest diameter of leaves rosette $(41.1 \mathrm{~cm})$. The lowest number of flower was recorded in S15 (8.67). Genotypes S6 (14.23), S13 (14.33) and S14 (14.33) had similar values for the number of flowers. The highest number of leaves was recorded in S14 (40.67) and S15 (40.00) genotypes. A high number of leaves was registered in S2 (34.33), differing statistically from $\mathrm{S} 14$.

The width of leaves varied from $2.47 \mathrm{~cm}(\mathrm{~S} 15)$ to $6.33 \mathrm{~cm}$ (S3). A good result concerning this trait was obtained by $\mathrm{S} 10$ $(6.30 \mathrm{~cm})$, but not differing statistically from S3. The data processed and interpreted with the Duncan's test show that the highest value for the length of leaves was registered in S5 genotype $(6.77 \mathrm{~cm})$. Appropriate values were obtained by $S 2$ $(6.30 \mathrm{~cm}), S 3(6.43 \mathrm{~cm}), S 4(6.00 \mathrm{~cm}), S 12(6.20)$ and $S 14(6.03$ $\mathrm{cm})$. Morphological traits evaluation in Saintpaulia genotypes could be useful in order to choose the right genotypes for further breeding programs.

\section{Phenotypic correlations}

Within the experiments on Saintpaulia genotypes in the current study, statistically assured phenotypical correlations were recorded (Figs. $2 \rightarrow 5$ ) among the various characteristic analyzed.

Pollen viability and germination are important in fertilization process (Ahmad et al., 2012; Francisco De Assis et al., 2011), therefore the relationship between these two variables is vital (Petrișor et al., 2012). The viability is a crucial parameter in obtaining the maximum potential of hybridization (Huang et al., 2004). Thus, between the two indicators, there were registered positive and direct correlations for 'Aloha Orchid' (S3), 'Crimson Ice' (S7), Saintpaulia jonantha H. Wendl. (S8), Saintpaulia rupicola B. L. Burtt (S13) and Saintpaulia grotei Engl. (S15) genotypes, which demonstrated that the two variables change in the same direction, hence the higher the viability is, the better the pollen germination is also (Prasad et al., 1999).

Fig. $2 \mathrm{~b}$ illustrates the correlation between the germination capacity and the number of flowers. The genotypes among which this correlation was direct and highly significantly positive are: 'Red Velvet' (S1), 'Lucky Ladybug' (S6), Saintpaulia jonantha H. Wendl. (S8) and Saintpaulia rupicola B.L. Burtt (S13) genotypes.

To be noted that among genotypes 'Jolly Red' (S2), 'Aloha Orchid' (S3), 'Park Avenue Blue' (S5), Saintpaulia jonantha H. Wendl. (S8), 'White Queen' (S9), 'Buffalo Hunt' (S12), Saintpaulia rupicola BL Burtt (S13) and 'Tomahawks' (S14), the correlation between the pollen viability and the number of flowers was direct and positive, which was in agreement with the results obtained by Prasad et al. (1999) (Fig. 3a). 
200

Table 1. Evaluation of variability of morphological traits in Saintpaulia genotypes

\begin{tabular}{|c|c|c|c|c|c|c|}
\hline \multirow{2}{*}{ Genotype code } & \multicolumn{6}{|c|}{ Morphological traits evaluated } \\
\hline & No. of flowers & Diameter of leaves rosette $(\mathrm{cm})$ & No. of leaves & Width of leaves $(\mathrm{cm})$ & Length of leaves $(\mathrm{cm})$ & Petiole length $(\mathrm{cm})$ \\
\hline S1 & $19.67^{\mathrm{bc}}$ & $24.77^{\mathrm{f}}$ & $17.33^{\mathrm{h}}$ & $3.67^{\mathrm{fg} g}$ & $4.53^{\mathrm{fg}}$ & $5.30^{\text {de }}$ \\
\hline S2 & $23.67^{\mathrm{ab}}$ & $29.87^{\mathrm{c}}$ & $34.33^{b}$ & $6.00^{\mathrm{b}}$ & $6.30^{c}$ & $5.00^{\mathrm{ef}}$ \\
\hline S3 & $16.67^{\text {cd }}$ & $28.23^{\mathrm{c}}$ & $21.67^{\mathrm{g}}$ & $6.33^{\mathrm{a}}$ & $6.43^{\mathrm{b}}$ & $6.33^{\mathrm{d}}$ \\
\hline S4 & $25.00^{\mathrm{a}}$ & $41.10^{\mathrm{a}}$ & $30.67^{\mathrm{de}}$ & $5.10^{\mathrm{de}}$ & $6.00^{\mathrm{cd}}$ & $9.23^{\mathrm{a}}$ \\
\hline S5 & $13.67^{\mathrm{e}}$ & $29.00^{\mathrm{d}}$ & $32.00^{\mathrm{d}}$ & $5.50^{c}$ & $6.77^{\mathrm{a}}$ & $8.87^{\mathrm{b}}$ \\
\hline 56 & $14.23^{\mathrm{d}}$ & $20.57^{\mathrm{g}}$ & $22.80^{\mathrm{fg}}$ & $3.70^{\mathrm{ef}}$ & $3.83^{\text {th }}$ & $3.90^{\mathrm{g}}$ \\
\hline S7 & $11.67^{\mathrm{f}}$ & $28.60^{e}$ & $26.33^{\mathrm{efg}}$ & $5.13^{\mathrm{de}}$ & $5.00^{d}$ & $5.13^{\text {def }}$ \\
\hline S8 & $10.00^{\mathrm{g}}$ & $23.53^{\mathrm{fg}}$ & $22.33^{\mathrm{fg}}$ & $5.40^{\mathrm{d}}$ & $5.00^{\circ}$ & $5.13^{\text {def }}$ \\
\hline S9 & $19.00^{\text {cd }}$ & $28.00^{\mathrm{f}}$ & $33.67^{b}$ & $3.43^{\mathrm{g}}$ & $5.07^{\mathrm{f}}$ & $3.50^{\mathrm{h}}$ \\
\hline S10 & $13.67^{c}$ & $21.93^{\mathrm{fg}}$ & $30.00 \mathrm{~d}^{\mathrm{ef}}$ & $6.30^{\mathrm{a}}$ & $5.60^{\circ}$ & $4.83^{\mathrm{g}}$ \\
\hline S11 & $13.67^{e}$ & $17.17^{\mathrm{i}}$ & $17.33^{\mathrm{h}}$ & $3.57 f^{5}$ & $4.70^{\mathrm{fg}}$ & $5.43^{\mathrm{d}}$ \\
\hline S12 & $16.67^{\text {cd }}$ & $35.40^{b}$ & $33.67^{c}$ & $5.67^{\circ}$ & $6.20^{c}$ & $4.87^{\mathrm{t}}$ \\
\hline S13 & $14.33^{\mathrm{d}}$ & $18.07^{\mathrm{h}}$ & $36.67^{b}$ & $3.07^{\mathrm{s}}$ & $4.50^{\mathrm{fg}}$ & $6.33^{c}$ \\
\hline S14 & $14.33^{\mathrm{d}}$ & $31.83^{b}$ & $40.67^{\mathrm{a}}$ & $5.87^{\circ}$ & $6.03^{\text {cd }}$ & $5.07 \mathrm{~d}^{\mathrm{ef}}$ \\
\hline S15 & $8.67^{8}$ & $13.60^{j}$ & $40.00^{2}$ & $2.47^{\mathrm{B}}$ & $3.40^{\mathrm{h}}$ & $3.00^{i}$ \\
\hline
\end{tabular}
$(0.44-0.52)$ width of leaves, \pm SD $(0.38-0.45)$ length of leaves and \pm SD $(0.34-0.40)$ petiole length. Small letters represent the statistical differences at $\mathrm{P}<0.05 \%($ Duncan test)
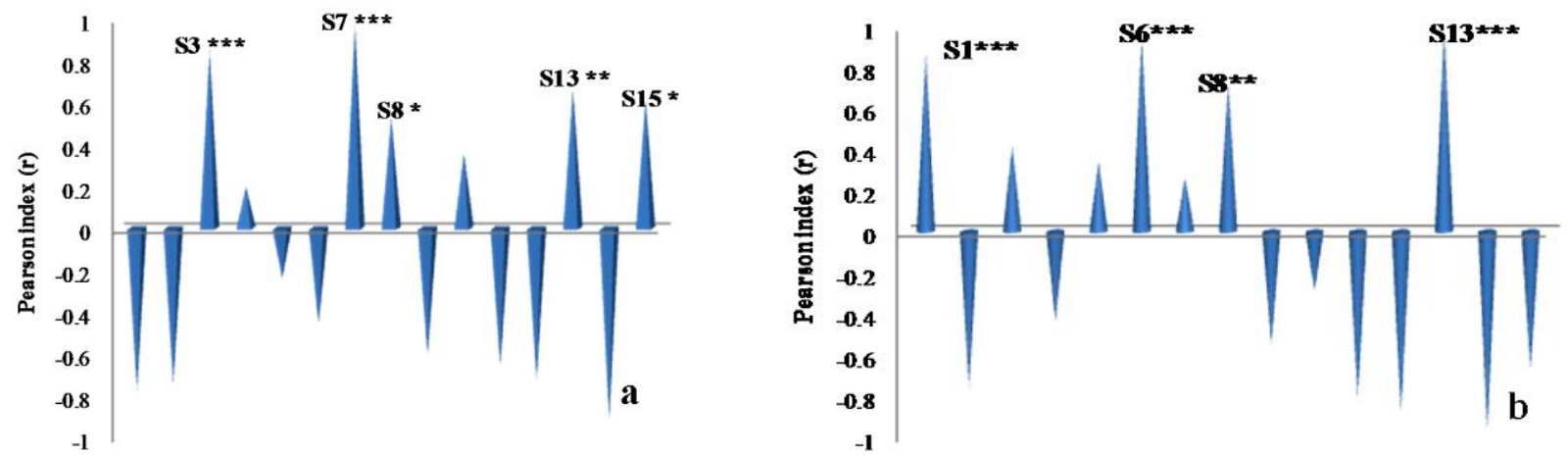

Fig. 2. Correlation between pollen viability $\mathrm{x}$ germination $(\mathbf{a})$ and pollen germination $\mathrm{x}$ no. of flowers $(\mathbf{b})$ in Saintpaulia genotypes $(14$ cases $\mathrm{P} 5 \%=$ $0.497, \mathrm{P} 1 \%=0.623, \mathrm{P} 0,1 \%=0.742$ according to Sestrașet al., 2012)
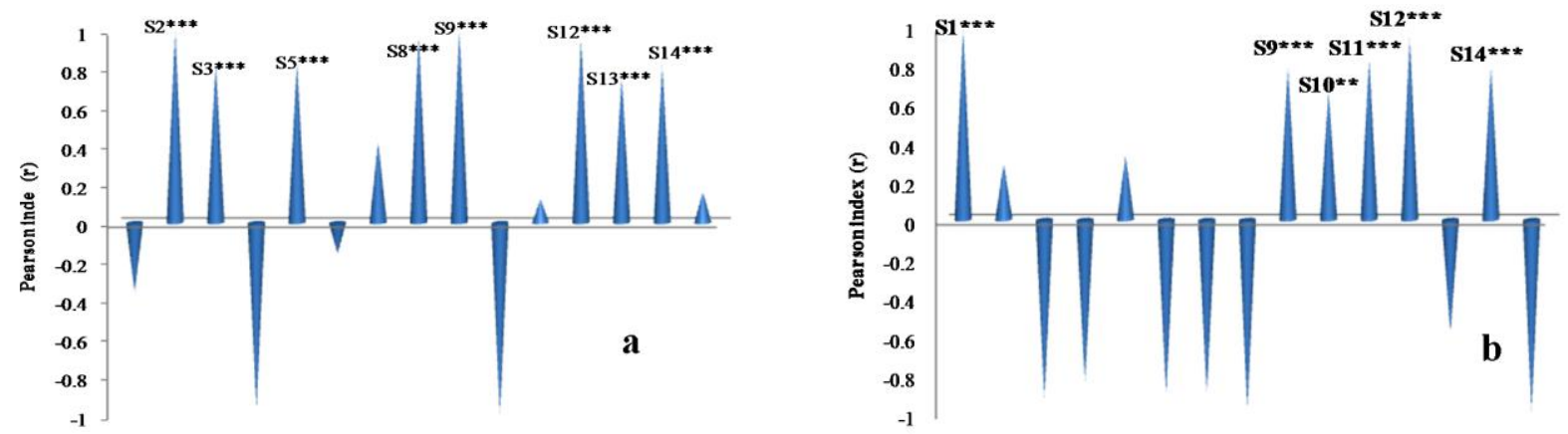

Fig. 3. Significant relationship between pollen viability $\mathrm{x}$ no. of flowers (a) and diameter of leaves rosette x petiole length (b) in Saintpaulia genotypes ( 14 cases $\mathrm{P} 5 \%=0.497, \mathrm{P} 1 \%=0.623, \mathrm{P} 0,1 \%=0.742$ according to Sestrașet al., 2012)
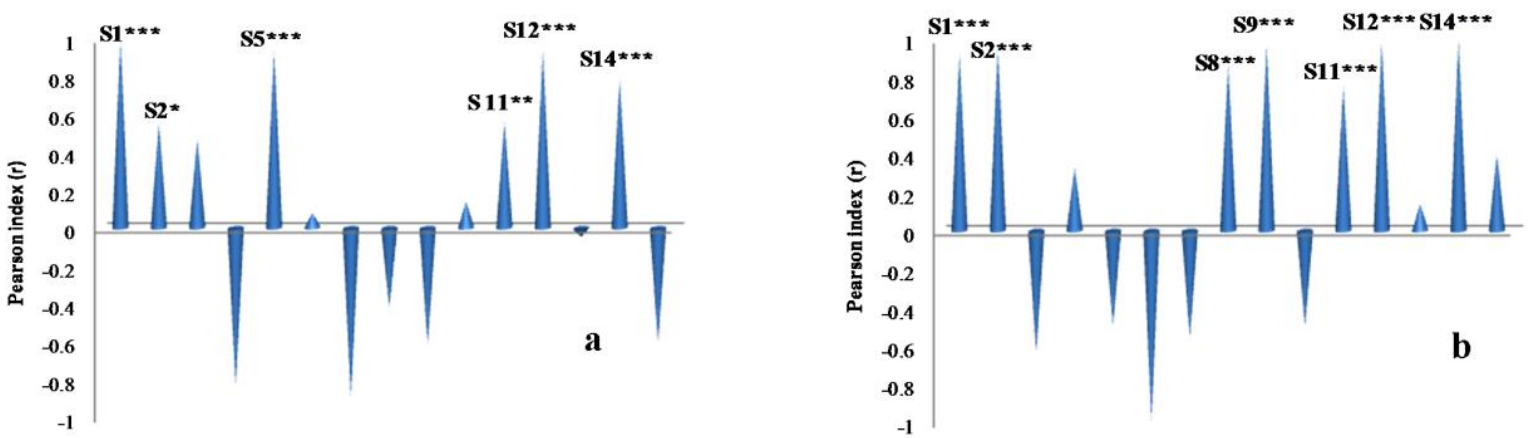

Fig. 4. Strong positive relationship between diameter of leaves rosette x no. of leaves (a) and no of leaves x width of leaves (b) in Saintpaulia genotypes ( 14 cases $\mathrm{P} 5 \%=0.497, \mathrm{P} 1 \%=0.623, \mathrm{P} 0,1 \%=0.742$ according to Sestrașet al., 2012) 

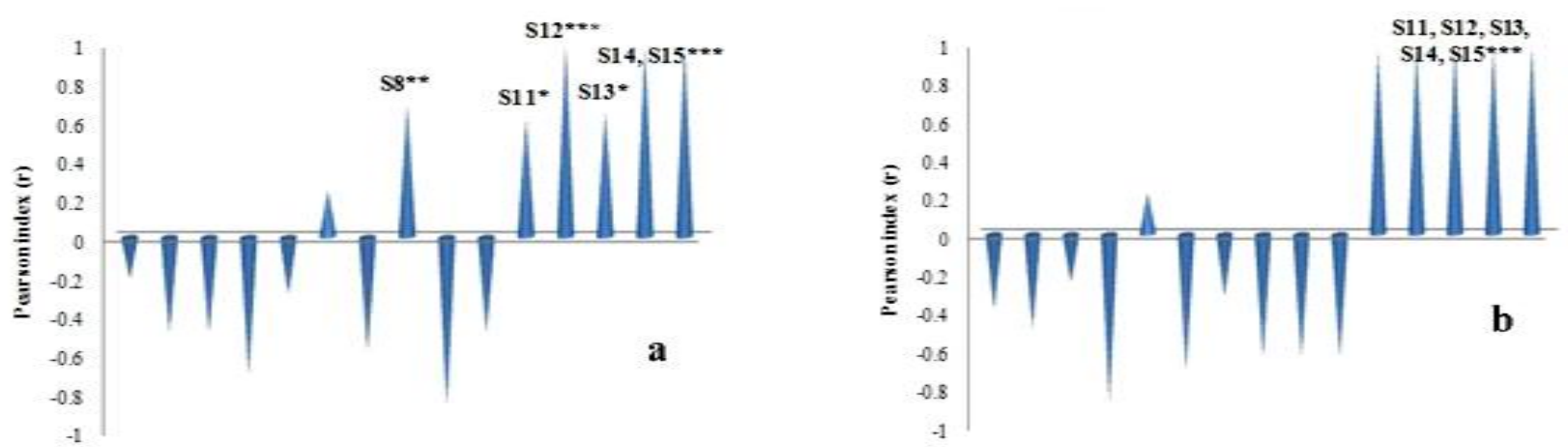

Fig. 5. Correlation between width of leaves $x$ leaves length $(\mathbf{a})$ and leaves length $x$ petiole length $(\mathbf{b})$ in Saintpaulia genotypes $(14$ cases $\mathrm{P} 5 \%=$ $0.497, \mathrm{P} 1 \%=0.623, \mathrm{P} 0,1 \%=0.742$ according to Sestraș et al., 2012)

Positive correlations were recorded between the diameter of plant rosette and the length of the leaf petioles for 'Red Velvet' (S1), 'White Queen' (S9), 'Painted Silk' (S10), 'Pink Pussycat' (S11), 'Buffalo Hunt' (S12) and 'Tomahawks' (S14) (Fig. 3b) genotypes. The leaf petiole can determine the position of leaves; hence, this correlation is also essential in terms of photosynthetic ratio, although in some cases the petiole length may indicate a lack of light intensity, due to an increase in cell size (Gonçalves $e t$ al., 2005).

The Pearson's index value $(\mathrm{r} \approx 1.00)$ showed significant positive correlations between the diameter of the leaves rosettes and the number of leaves in 'Red Velvet' (S1), 'Jolly Red' (S2), 'Park Avenue Blue' (S5), 'Pink Dolls' (S11), 'Buffalo Hunt' (S12) and 'Tomahawks' (S14) (Fig. 4) genotypes. An increased number of leaves mean a larger area of nutrition, higher energy transfer and therefore a better support for the development of pollen grain (Chanda and Singh, 2002).

The correlation between the number of leaves and their width was significantly positive for 'Red Velvet' (S1), 'Jolly Red' (S2), Saintpaulia jonantha H. Wendl. (S8), 'White Queen' (S9), 'Pink Pussycat' (S11), 'Buffalo Hunt' (S12) and 'Tomahawks' (S14) (Fig. 4b) genotypes. This correlation was influenced by the environmental conditions, the thickness of foliole and the size of cells (Chanda and Singh, 2002; Gonçalves et al., 2005; Mokhtarpour et al., 2010).

Positive correlations between the width of leaves and their length were also recorded in the following genotypes: Saintpaulia jonantha H. Wendl. (S8), 'Pink Pussycat' (S11), 'Buffalo Hunt' (S12), Saintpaulia mpicola B.L. Burtt (S13), 'Tomahawks' (S14), Saintpaulia grotei Engl. (S15) (Fig. 5). These parameters are important in the assessment of plant growth. Their analysis is required to determine growth indices, which give direct information on assimilation, photosynthetic performance, photochemical efficiency and a balanced development of plants (Gonçalves et al., 2005; Mokhtarpour et al., 2010). The correlation between the length of leaves and the length of the petiole was direct and positive in Saintpaulia jonantha $\mathrm{H}$. Wendl. (S8), 'Pink Pussycat' (S11), 'Buffalo Hunt' (S12), Saintpaulia rupicola B.L. Burtt (S13), 'Tomahawks' (S14) and Saintpaulia grotei Engl. (S15) genotypes (Fig. 5b).

The correlations between the main phenotypical traits, viability and the germinability of palynomorphs depend on genotype, but can be influenced by exogenous factors technological indicators and are in tight relation with the chemical composition of pollen (Saniet al, 2013; Žilićet al.,2014).

\section{Conclusions}

The obtained results showed that the analyzed morphological traits (number of flowers, diameter of leaves rosette, number of leaves, length and width of leaves, petiole length) are promising items to be considered in further breeding programs. Genotypes S3, S4, S5, S14 and S15 were noted with the highest values for the most important morphological characters. The correlations made between the main phenotypical traits revealed the existence of direct and positive correlations between the sustainability and the germinability of palymorphs in Saintpaulia $\mathrm{H}$. Wendl genotypes There were recorded significant positive correlations between pollen viability and the number of flowers, but also between germination and the number of flowers per plant. The genotypes recommended for breeding works are: 'Aloha Orchid', 'Crimson Ice', Saintpaulia jonantha H. Wendl, Saintpaulia mupicola B. L. Burtt and Saintpaulia grotei Engl. These genotypes came into evidence by very good pollen germination and experienced a high viability. The study of correlations between viability, germination of pollen and the morphological traits contributes in the improvement of the process of obtaining new cultivars and choosing the genitors in breeding.

\section{Acknowledgements}

This paper was published under the frame of European Social Fund, Human Resources Development Operational Programme 2007-2013, projectno.POSDRU/159/1.5/S/132765.

\section{References}

Ahmad S, Rana A, Rajendra S, Agnihotri RK (2012). Effect of different media and boric acid on pollen germination and tube growth of Tribulus terrestris - a traditional medicinal plant. International Journal of Pharmaceutical Sciences Review and Research 13(2):7779.

Baciu AD, Mihalte L, Sestras AF, Sestraș RE (2010). Variability of decorative traits, response to the Aphis fabae attack and RAPD diversity in different genotypes of Calendula. Not Bot Horti Agrobo 38(2):265-270.

Barros LB, Moreira RMP, Ferreira JM (2010). Phenotypic, additive genetic and environment correlations of maize landraces populations in family farm systems. Scientia Agricola 67(6):685-691. 
202

Bodhipadma K, Noichinda S, Thaiyanto P, Leung DWM (2013). Morphology, viability, and germinability of pollen from two forms of Nymphaea nouchali var. versicolor, a day-blooming waterlily. ScienceAsia 39(2):214218.

Chanda SV, Singh YD (2002). Estimation of leaf area in wheat using linear measurements. Plant Breeding and Seed Science 46(2):75-79.

Daud N, Taha RM (2008). Plant regeneration and floral bud formation from intact floral parts of African violet (Saintpaulia ionantha $\mathrm{H}$ Wendl.) cultured in vitro. Pakistan Journal of Biological Sciences 11(7):1055-1058.

De Assis SNF, Geraldo MAB, Barbosa JC (2011). In vitro viability of "bacury" pollen grains. Revista Brasiliera de Fruticultura 33:593600.

Fang JY, Traore S (2011). In vitro mutation induction of Saintpaulia using ethyl methanesulfonate. HortScience 46(7):981-984.

Ghasemi Y, Nematzadeh GA, Omran VG, Dehestani A, Hosseini S (2012). The effects of explant type and phytohormones on african violet (Saintpaulia ionantha) micropropagation efficiency. Biharean Biologist 6(2):73-76.

Gonçalves CFJ, Barreto DCS, Santos Junior UM, Fenandes AV, Sampaio PTB, Buckeridge MS (2005). Growth, photosynthesis and stress indicators in young rosewood plants (Aniba rosaeodora Ducke) under different light intensities. Braz J Plant Physiol 17(3):325-334.

Gudadhe SP, Dhoran VS (2012). Observation on pollen viability, in vitro pollen germination and pollen tube growth in Chlorophytum comosum (Thunb) Jacq. and Asparagus officinalis L. International Journal of Current Research 4(07):022-027.

Harrison CJ, Möller M, Cronk QCB (1999). Evolution and development of floral diversity in Streptocarpus and Saintpaulia. Ann Bot 84(1):49-60.

Huang Z, Zhu J, Mu X, Lin J (2004). Pollen dispersion, pollen viability and pistil receptivity in Leymuschinensis. Ann Bot 93:295-301.

Khan AA, Alam MA, Alam MK, Alam MJ, Sarker ZI (2013). Genotypic and phenotypic correlation and path analysis in durum wheat (Triticum turgidum L. var. durum). Bangladesh J Agril Res 38(2):219-225.
Kolehmainen J, Mutikainen P (2007). Population stage structure, survival and recruitment in the endangered East African forest herb Saintpaulia. Plant Ecol 192:85-95.

Kolehmainen J, Korpelainen H (2008). Morphotypes, varieties, or subspecies?: Genetic diversity and differentiation of four Saintpaulia (Gesneriaceae) morphotypes from the East Usambara Mountains, Tanzania. Botanical Journal of the Linnean Society 157(2):347355.

Miranto M (2005). Living collections of botanic gardens as a means of ex situ conservation - A case study of African violets (Saintpaulia) in Europe. Univ. of Helsinki, Dep. of Biological and Environmental Sciences, MSc Diss.

Mokhtarpour H, Christopher BST, Ghizan S, Ahmad BS, Mohammad EA, Behnam K (2010). Non-destructive estimation of maize leaf area, fresh weight, and dry weight using leaf length and leaf width. Communications in Biometry and Crop Science 5(1):19-26.

Petrișor C, Mitre V, Mitre I, Jantschi L, Balan CM (2012). The rate of pollen germination and the pollen viability at ten apple cultivars in the climatic conditions of Transylvania. Bulletin UASMV. Horticulture 69(1):417-418.

Prasad PVV, Craufurd PQ, Summerfield RJ (1999). Fruit number in relation to pollen production and viability in groundnut exposed to short episodes of heat stress. Ann Bot 84: 381-386.

Robey MJ (1988). African violets: gift from nature. New York \& London: Cornwall Books.

Sani AM, Abbas HK, Moradi E (2013). Chemical composition and nutritional value of saffron's pollen (Crocus sativus L.). Nutr Food Sci 43(5):490-495.

Sestraș RE, Ardelean M, Cordea IM, Sestraș AF (2012). Biostatistics and forestry experimental technique (in Romanian). AcademicPres, Cluj-Napoca, $91 \mathrm{p}$.

Sestraş RE (2012). Plant breeding (in Romanian). AcademicPres, Cluj Napoca.

Žilić S, Vančetović J, Janković M, Maksimović V (2014). Chemical composition, bioactive compounds, antioxidant capacity and stability of floral maize (Zea mays L.) pollen. J Funct Foods 10:6574. 